\title{
Plants used in traditional beekeeping in Burkina Faso
}

\author{
Schweitzer Paul ${ }^{1}$, Nombré Issa ${ }^{2,3}$, Aidoo Kwamé ${ }^{4}$, Boussim I. Joseph ${ }^{2}$ \\ ${ }^{1}$ Laboratoire d'Analyses et d'Ecologie Apicole Centre d'Etudes Techniques Apicole de Moselle, Guenange, France \\ ${ }^{2}$ Institut des Sciences, Ouagadougou, Burkina Faso; nombre_issa@yahoo.fr \\ ${ }^{3}$ Laboratoire de Biologie et Ecologie Végétales UFR Science et Technique Université de Ouagadougou, Ouagadougou, Burkina Faso \\ ${ }^{4}$ International Stingless Bee Centre, Department of Entomology and Wildlife, University of Cape Coast, Cape Coast, Ghana
}

Received 4 January 2013; revised 5 August 2013; accepted 25 August 2013

Copyright (C) 2013 Schweitzer Paul et al. This is an open access article distributed under the Creative Commons Attribution License, which permits unrestricted use, distribution, and reproduction in any medium, provided the original work is properly cited.

\begin{abstract}
Beekeeping is one of the recommended approaches in the implementation of poverty alleviation programs in rural areas of Burkina Faso. However, plants that are important in beekeeping have not been identified. The use of parts and organs of plants by beekeepers and their methods of harvesting remain unknown. These limit the conservation efforts of these important plants and affect beekeeping development. The study was carried out in the south-central, eastcentral regions and in Comoé and Boucle of Mouhoun regions of Burkina Faso. The objective of the study was to identify the plants species used by traditional beekeepers, the different uses made of these plant parts and organs and then to discuss the impact of these activities on the survival of the plant resources. An ethnoapiculture survey was conducted in the main apiculture zone of Burkina Faso, using semistructured interviews. The methodology of botanical coherence or convergence was applied to classify botanical species. Results showed that 35 botanical species were used in traditional beekeeping. The use of plant parts or organs in traditional hives construction represents $55 \%$, attraction of wild swarms in new beehives is $37.50 \%$ and use as a torch or as a smoker, $7.50 \%$. The barks are the organs most used. Trees are botanical type most used. The results are not exhaustive and therefore other additional studies need to be carried out. In order to sustain the use of these important plants, their growing in nursery and their planting in the field are recommended.
\end{abstract}

Keywords: Beekeeping; Melliferous Plants; Pollinating; Biodiversity; Burkina Faso

\section{INTRODUCTION}

Honeybees are since 2006 victims of colony collapse disorder or (CCD) ([1-3]). Many well intentioned suggestions as to the possible causes of colony losses, including such improbable ideas as mobile telephones, genetically modified crops and nanotechnology, have perhaps overshadowed much more likely explanations such as pests and diseases, pesticides, loss of forage and inappropriate beekeeping practices [2]. Bees are the major pollinators of wild plants and crops in terrestrial ecosystems. Honeybees are known to contribute significantly to the provision of this essential ecosystem service of pollination [4-6]. They are also bio-indicators for environment pollution $[7,8]$ and beekeeping is an effective means to generate monetary incomes that support the livelihood of rural communities. Numerous studies have demonstrated the economic value of honeybees to the agricultural industry of the world $[9,10]$. In Africa, especially areas in south of Sahara and particularly in Burkina Faso, this phenomenon is not fully known because of the lack of scientific studies [11]. [6] stated that beekeepers and honey hunters are sometimes perceived to cause damages to forests, through the careless use of fire during harvesting and because they kill trees to make beehives. So, traditional beekeeping has been considered as harmful to biodiversity conservation [12]. Others authors differentiate traditional beekeeping from honey hunting as contributing to the increase in honey bee number. The roles of honeybees in providing ecosystem services is a function of their number in the beehive and varies according to the type of beehive used [13].

Burkina Faso has undertaken the modernization of its apiculture since 1987. Studies had been done on the melliferous plants $[14,15]$ and on the plant organs used to attract swarms of the local honeybee Apis mellifera adansonii Latreille into newly installed beehives [16]. Traditional beekeeping is widespread in Burkina Faso and their activities understand in the exploitation of plant 
parts and organs described as “extractivism” may have conservation undertones [17]. Studies on the impact of this activity on colony loss and other effects on the environment have not been carried out. The harvest technologies of plant organs or parts remain unrecognized, limiting the conception of preservation efforts of melliferous plants. This lack of information can moreover constitute a handicap in the development of beekeeping. It is to contribute to raising this constraint in relationship with the lack of information that the present study aims to provide knowledge on the used in traditional beekeeping. It will identify the various uses of the plant parts and organs and discuss their impacts on plant resources sustainability and then suggest solutions for a sustainable management of the identified plants.

\section{MATERIAL AND METHODS}

\subsection{Study Area}

The study was carried out in the villages of Nazinga (south-central region), Garango (east-central region), Tiefora (Comoé region) and Dédougou (Boucle of Mouhoun region) (Figure 1).

These communities fall within the main beekeeping zones made up of the north and south Soudanian phytogeographical sector of Burkina Faso.

Agriculture (crop cultivation and animal breeding) is the main activity of the population. In all the regions, crops (Sorghum guineense Staph., Zea mays Linn., Oryza sativa Linn., and Dioscorea dumetotum (Kunt) Pax.) are dominant.

The vegetation is predominantly savannas with arusticlandscapes dominated by species such Vitellaria paradoxa Gaertn, Tamarindus indica Linn., Parkia biglobosa (Jacq.) Benth, Lannea microcarpa Engl. \& K. Krause, Adansonia digitata Linn., Faidherbia albida (Del.) A. Chev.; the groupings of Anogeissus leiocarpus (DC.)

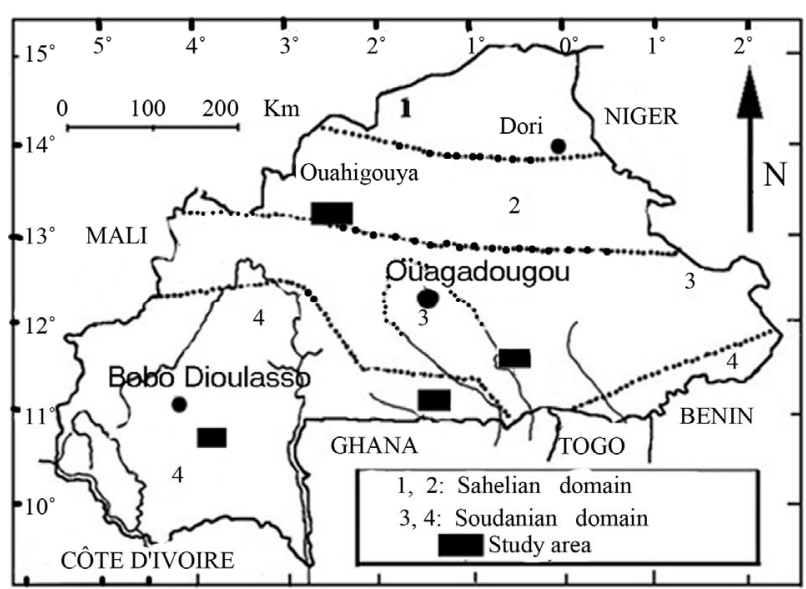

Figure 1. Location of the study area.
Guil. \& Perr. and planted species as Mangifera indica Linn., Eucalyptus camaldulensis Dehnhard, Azadirachta indica A. Juss, Khaya senegalensis (Desn.) A. Juss, Anacardium occidentale Linn., Borassus aethiopum Mart., Psidium guajava Linn., Cariaca papaya Linn., Annona squamosa Linn., and Citrus sinensis (Linn.) Osbeck.

\subsection{Methods}

Ethno-apicultural investigations and field observations were carried out using semi-structured inquiry cards on traditional beekeepers who are 25 years of age and possessing colonized traditional beehives. The names of plants used were transcribed into the following local languages: Gourounsi for Nazinga zone; Bissa for Garango zone and Dioula for Tiéfora and Dédougou zones. The plant species scientific identification was made referring to [18]. The plants parts and organs used by beekeepers were identified from responses obtained from at least 10 beekeepers. A total of 103 beekeepers were interviewed.

\section{RESULTS}

\subsection{Different Plant Parts or Organs Used}

The results showed that the barks and fibers with $37.5 \%$ of utilizations constituted the most organs used (Figure 1). The grass, the aerial organs, the thatches of graminaceous and the inflorescences constituted the group of plants aerial part (32.5\%). The twigs constituted $12.5 \%$, the fruits and seeds $10 \%$, leave $5 \%$ and the tubers were less used (2.5\%).

\subsection{Plants Used and Their Utilizations}

The parts or organs of 35 botanical species were used in the traditional beekeeping practices in Burkina Faso (Table 1).

Three kinds of utilization of the plant parts or organs were dominants (Table 1). The first concerned the use in the new traditional beehives construction. It repre-

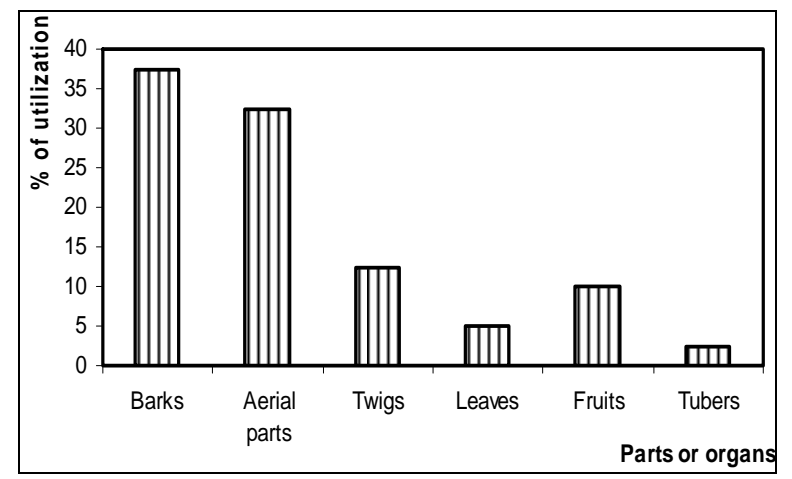

Figure 2. Different plant parts or organs used in traditional beekeeping. 
sented 55\%. Indeed, beehives can be made with barks, hollowed out tree trunks, plaited straws or twigs.

The second represented the attraction of wild swarms into newly established beehives. It represented 37.50\%. Indeed, plant parts or organs can be used as swarm baits substituting the Aristée perfumes, the honeybees' charm or comb foundations used in modern beekeeping.

The third is the use as a torch to light beehives inside or as a smoker during honey harvesting. It represented $7.50 \%$.

\subsection{Botanical Type Used}

In the biological type, trees were the most used (44\%); followed in order by the grass (31\%), the shrubs (22\%) and the lianas (3\%) (Figure 3).

Table 1. The use of plant parts and organs in traditional beekeeping in the Burkina Faso.

\begin{tabular}{|c|c|c|}
\hline Scientifique names & Parts or organs used & Utilizations \\
\hline Acacia seyal Del. & Fruits & Swarms attraction \\
\hline Combretum glutinosum Perr. ex DC & Twigs & Swarms attraction \\
\hline Ctenium newtonii Hack. & Thatches & Swarms attraction \\
\hline Cymbopogon schoenanthus subsp. proximus (Hochst. ex A. Rich.) M. \& W & Inflorescences & Swarms attraction \\
\hline Dicoma tomentosa Cass. & Aerial organs & Swarms attraction \\
\hline Dioscorea dumetorum (Kunth) Pax & Tubers & Swarms attraction \\
\hline Diospyros mespiliformis Hochst. ex A. DC. & Leaves & Swarms attraction \\
\hline Guiera senegalensis J. F. Gmel. & Twigs & Swarms attraction \\
\hline Hyptis spicigera Lam. & Aerial organs & Swarms attraction \\
\hline Leucas martinicensis (Jacq.) Ait. & Aerial organs & Swarms attraction \\
\hline Ocimum americanum Linn. & Aerial organs & Swarms attraction \\
\hline Piliostigma reticulatum (DC.) Hochst. & Fruits & Swarms attraction \\
\hline Piliostigma thonningii (Schum.) Milne-Redhead & Fruits & Swarms attraction \\
\hline Andropogon ascinodis C. B. Clarke & Thatches & Honey harvest \\
\hline Andropogon gayanus Kunth & Thatches & Honey harvest \\
\hline Andropogon pseudapricus Stapf & Thatches & Honey harvest \\
\hline Andropogon ascinodis C. B. Clarke & Thatches & Beehive construction \\
\hline Andropogon gayanus Kunth & Thatches & Beehive construction \\
\hline Andropogon pseudapricus Stapf & Thatches & Beehive construction \\
\hline Borassus aethiopum Mart. & Leaves & Beehive construction \\
\hline Burkea africana Hook. & Bark & Beehive construction \\
\hline Daniellia oliveri (Rolfe) Hutch. \& Dalz. & Bark & Beehive construction \\
\hline Detarium microcarpum Guill. \& Perr. & Bark & Beehive construction \\
\hline Hibiscus asper Linn. & Fibers & Beehive construction \\
\hline Isoberlinia doka Craib \& Stapf & Bark & Beehive construction \\
\hline Lannea acida A. Rich. & Fibers & Beehive construction \\
\hline Loudetia togoensis (Pilger) C. E. Hubbard & Thatches & Beehive construction \\
\hline Piliostigma reticulatum (DC.) Hochst. & Fibers & Beehive construction \\
\hline Piliostigma thonningii (Schum.) Milne-Redhead & Fibers & Beehive construction \\
\hline Prosopis africana (Guill. \& Perr.) Taub. & Bark & Beehive construction \\
\hline Pseudocedrela kotschyi (Schweinf.) Harms & Bark & Beehive construction \\
\hline Pterocarpus erinaceus Poir. & Bark & Beehive construction \\
\hline Saba senegalensis (A. DC.) Pichon & Twigs & Beehive construction \\
\hline Fluggea virosa (Roxb. ex Willd.) Baill & Twigs & Beehive construction \\
\hline Tamarindus indica Linn. & Fibers & Beehive construction \\
\hline Terminalia avicennioides Guill. \& Perr & Bark & Beehive construction \\
\hline Vitellaria paradoxa Gaertn. & Bark & Beehive construction \\
\hline Xeroderris stuhlmannii (Taub.) Men & Bark & Beehive construction \\
\hline
\end{tabular}




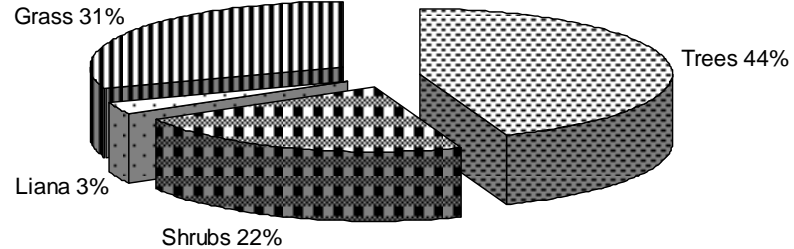

Figure 3. Different plants biological types used in traditional beekeeping.

\section{DISCUSSION}

In the traditional beekeeping practices, different plants, parts or organs are used by the beekeepers in different ways. The construction of beehives is more important in the utilization of plants and also their parts or organs. The technology used to remove these parts or organs can be negative for the environment because it affects the regeneration and the survival of the plants used. Indeed, according to [17], the cutting down has negative impacts on the individual tree, because, even if it presents a potential of stump rejections, they have only very slight chance to survival. That will appear as habitat degradation and outright destruction and can be the major causal factor in the decline of bees [5].

Often, the plants used were also excellent nectar species and then the loss of trees has negative implications for beekeepers because they lose food and nesting sites for wild bees, materials for building hives and places to keep hives. However, beekeepers must make deliberate and conscious efforts to protect and conserve forests in which their bees forage, despite their dependency on these resources.

There are also positives impacts on traditional beekeeping practices. Indeed, nesting honeybees in appropriate way allows them to increase their number that will increase their role (pollinating, honey production). Often, the traditional beekeepers breed their honeybees even if the hives used are rudimentary; and they only use the smoke of burned thatch to hunt honeybees during the harvest [16]. According to [17], the removal or whatever organ collected is mostly made to secure not only the survival of the exploited individual, but also the regeneration of the resource in a reasonable lapse of time. Furthermore, according to [6], the development of traditional beekeeping based on keeping colonies, to the detriment of the honey hunting can increase the honeybees' number per beehive and even per region, involving thus an increase of their pollinating role. This development minimizes the destructive effects of traditional beekeeping on honeybees on one hand and the environment on the other. Also, according to [16], the utilization of plant organs or parts to attract honeybee swarms in newly established beehives contributes to reduce the installation costs of beekeeping projects development.
According to [6], the technologically modern man has contributed to honeybees declines in Africa. This is evident in that bee diversity and abundance is much greater on crops in areas surrounded by natural vegetation than in ecosystems that have been widely transformed by agriculture and other exotics along with removal of natural vegetation through urbanization.

\section{CONCLUSION}

Traditional beekeeping contributes greatly to biodiversity conservation in Burkina Faso. Despite the negative effects that are attributed to some of its activities, it allows for the establishment and management of wild swarms of honeybees in appropriated ways for hive products. The pollinating role of honeybees in the ecosystem is therefore enhanced. Plants, parts and organs are used at different levels in this system of apiculture. The effects of the use of plants and their organs in traditional beekeeping practices on the vegetation and the environment remain negligible. Traditional beekeepers therefore sustain the populations of honeybees in the environment which contribute to the essential ecosystem service of pollination and biodiversity conservation. Negative practices of wild honey hunting should be replaced with traditional beekeeping.

\section{REFERENCES}

[1] Chagnon, M. (2008) Causes et effets du déclin mondial des pollinisateurs et les moyens d’y remédier. Fédération Canadienne de la Faune. Bureau régional du Québec.

[2] Neumann, P., and Carreck, N.L. (2010) Honey bee colony losses. Journal of Apicultural Research, 49, 1-6. doi:10.3896/IBRA.1.49.1.01

[3] Kluser, S., Neumann, P., Chauzat, M.-P. and Pettis, J.S. (2010) Global honey bee colony disorder and other threats to insect pollinators. UNEP.

[4] Vaissière, B., Morison, N. and Carré, G. (2005) Abeilles, pollinisation et biodiversité. Abeilles \& Cie, 3, 10-14.

[5] Brown, M.J.F. and Paxton, R.J. (2009) The conservation of bees: A global perspective, Apidologie, 40, 410-416. doi:10.1051/apido/2009019

[6] Eardley, C.D., Gikungu, M. and Schwarz, M.P. (2009) Bee conservation in Sub-Saharan Africa and Madagascar: Diversity, status and threats, Apidologie, 40, 355-366. doi:10.1051/apido/2009016

[7] Chauzat, M.-P., Faucon, J.-P., Martel, A.-C., Lachaize, J., Cougoule, N. and Aubert, M. (2006) Les pesticides, le pollen et les abeilles LSA, 216, 11-12.

[8] Bogdanov, S. (2006) Contaminants of bee products. Apidologie, 37, 1-18. doi:10.1051/apido:2005043

[9] Krell, R. (1996) Value-added products from beekeeping. FAO Agricultural Services Bulletin No. 124.

[10] Bradbear, N. (2010) Le rôle des abeilles dans le dévelop- 
pement rural. Manuel sur la récolte, la transformation des produits et services dérivés des abeilles. FAO, Rome, PFNL 19.

[11] Dietemann, V., Pirk, C.W.W. and Crewe, R. (2009) Is there a need for conservation of honeybees in Africa? Apidologie, 40, 285-295. doi:10.1051/apido/2009013

[12] Fisher, F.U. (1993) L'élevage des abeilles dans l'économie de base de la savane arborée de Miombo au Centre de l'Afrique Australe. Document du Réseau Forestier Pour le Développement Rural, 15, 3-11.

[13] Foucault, B. (2010) Ethonographie de quelques ruches traditionnelles. Colloque sur les Journées d'échanges sur l'abeille et l'apiculture, 22-27 Avril 2005, Lille, 121-128

[14] Guinko, S., Guenda, W., Tamini, Z. and Zoungrana, I. (1992) Les plantes mellifères de la zone Ouest du Burkina Faso. Etudes flor. Vég. Burkina Faso, 1, 27-46.
[15] Nombré, I., Schweitzer, P., Sawadogo, M., Boussim, J.I. and Millogo-Rasolodimby, J. (2009) Assessment of melliferous plant potentialities in Burkina Faso. African Journal of Ecology, 47, 622-629. doi:10.1111/j.1365-2028.2009.01034.x

[16] Nombré, I., Schweitzer, P., Boussim, I.J., Millogo/Rasolomdimby, J. (2009) Plantes utilisées pour attirer les essaims de l'abeille domestique (Apis mellifera adansonii Latreille) au Burkina Faso. International Journal of Biological and Chemical Sciences, 3, 840-844.

[17] Aubertin, C., De Castro, A.L., Empenire, L., Lescure, J.-P., Mitja, D. and Pinton, F. (1993) Les activités extractivistes en Amazonie Centrale: Une première synthèse d'un projet multidisciplinaire. ORSTOM/INPA.

[18] Arbonnier, M. (2002) Arbres, arbustes et lianes des zones sèches d'Afrique de l'Ouest. CIRAD, MNHN, UICN. 